\title{
GAS EXCHANGE CHARACTERISTICS AND CHLOROPHYLL PIGMENT OF OIL PALM SEEDLINGS UNDER INFLUENCE OF BIOINOCULANTS
}

\author{
SUNEETHA, $V^{\star}$; RAMACHANDRUDU, $K^{\star \star}$ and SURESH, $K^{\star *}$
}

\begin{abstract}
The performance of bioinoculants and chemical fertilisers on net photosynthetic rate (Pn), transpiration rate (E), stomatal conductance (Gs), inter cellular $\mathrm{CO}_{2}$ concentration (Ci), chlorophyll, reducing sugars and total phenols in leaves and total seedling dry matter was assessed in oil palm seedlings grown in nursery for 12 months. Bioinoculants viz. Azotobacter chroococcum, Azospirillum brasilense, Bacillus megaterium, Frateuria aurantia, and Glomus aggregatum were used individually, combindly and integrated with chemical fertilisers. There were significant differences among the treatments used in experiment for various physiological and biochemical characters. Of all the treatments, integrated use of microbial fertilisers with $25 \%$ of recommended dose of chemical fertilisers (RDF) has emerged as the best promising treatment in influencing the above mentioned characters. The results of the study clearly indicated that minimal dose of chemical fertilisers $(25 \%$ RDF) may be required for exploiting the best possible growth benefits from bioinoculants.
\end{abstract}

Keywords: oil palm seedlings, bioinoculants, photosynthesis, chlorophyll, reducing sugars, phenols.

Date received: 4 August 2018; Sent for revision: 25 August 2018; Accepted: 25 November 2018.

\section{INTRODUCTION}

Oil palm (Elaeis guineensis Jacq.) is a perennial crop with economic life span of 30 years. The growth and yield of oil palm mainly depend on the quality of seedlings produced in the nursery. Being a heavy feeder, nutrition at the nursery stage is of paramount importance for establishment of healthy and productive commercial oil palm plantations. Microbial inoculants are promising components for integrated solutions to agro-environmental problems because bioinoculants possess the capacity to promote plant growth, enhance nutrient availability and uptake and support the plant health

\footnotetext{
Biotechnology,

Jawaharlal Nehru Technological University,

Hyderabad, Telangana 500085, India.

E-mail: suryadevarav@yahoo.co.in

** Crop Production,

ICAR-Indian Institute of Oil Palm Research,

Pedavegi West Godavari District,

Andhra Pradesh 534450, India.
}

by improving the microflora (Han and Lee, 2005). Hence, there is a great need for suitable substitute for inorganic fertilisers which are seriously upsetting soil fertility and soil health.

Azospirillum inoculation increased photosynthetic rate of oil palm seedlings as compared to that of control (Amir et al., 2001). Aseri and Rao (2005b) reported that efficient strains of nitrogen fixing bacteria (Azotobacter chroococcum and Azospirillum brasilense) and AMF-Glomus sp. were found to improve the chlorophyll content in leaves of pomegranate seedlings during nursery stage. Rhizobacteria (Azospirillum and Bacillus sp.) inoculated oil palm seedlings showed positive response in enhancing root and top dry matter under field nursery conditions (Amir et al., 2005). Gas exchange measurements and biochemical parameters are highly useful for comparing and understanding growth and vigour of oil palm seedlings. As no efforts in this line of work in India, the present study was conducted to evaluate influence of microbes on physiological and biochemical parameters of oil palm seedlings. 


\section{MATERIALS AND METHODS}

The present investigation was carried out at the Indian Institute of Oil Palm Research, Pedavegi, Andhra Pradesh State, India for two consecutive years. The experimental site is located at $16^{\circ} 43^{\prime} \mathrm{N}$ and $81^{\circ} 09^{\prime} \mathrm{E}$ with a mean sea level of $13.41 \mathrm{~m}$. Average annual temperature ranged from $21.8^{\circ} \mathrm{C}$ to $34.8^{\circ} \mathrm{C}$ in the first year and from $19.6^{\circ} \mathrm{C}$ to $36.7^{\circ} \mathrm{C}$ during the second year. Average relative humidity was $69.3 \%$ during the first year and $67.7 \%$ in the second year. Total amount of rainfall received was $1813.7 \mathrm{~mm}$ and $1026 \mathrm{~mm}$ during the first and second years, respectively.

\section{Experimental Details}

The nursery trial was laid out in completely randomised design (CRD) with 11 treatments replicated five times and 30 seedlings in each treatment. Treatments used were $\mathrm{T}_{1}$-Azotobacter chroococcum, $\mathrm{T}_{2}$-Azospirillum brasilense, $\mathrm{T}_{3}$-Bacillus megaterium, $\mathrm{T}_{4}$-Frateuria aurantia, $\mathrm{T}_{5}$-Glomus aggregatum, $\mathrm{T}_{6}-$ Consortium of bioinoculants, $\mathrm{T}_{7}-$ Consortium of bioinoculants $+25 \%$ recommended dose of chemical fertilisers (RDF), $\mathrm{T}_{8}$-Consortium of bioinoculants $+50 \%$ RDF, $\mathrm{T}_{0}$-Consortium of bioinoculants+75\% RDF, $\mathrm{T}_{10}-100 \%$ RDF and $\mathrm{T}_{11}{ }^{-}$ Control without bioinoculants and chemical fertilisers. Commercially, $30 \mathrm{~g}$ nitrogen $(\mathrm{N}), 38 \mathrm{~g}$ phosphorus $(\mathrm{P})$ and $25 \mathrm{~g}$ potassium $(\mathrm{K}) /$ seedling/ year are applied to oil palm nursery in India. Tank silt and cattle manure mixed in 2:1 ratio $(\mathrm{v} / \mathrm{v})$ was used as a potting mixture (Table 1) for raising oil palm nursery for 12 months in double stage nursery system i.e., primary stage for four months under ultraviolet (UV) stabilised high density polyethylene (HDPE) agro shade net house with $50 \%$ shade and secondary stage for eight months in open condition.

TABLE 1. PHYSICO-CHEMICAL CHARACTERISTICS OF POTTING SOIL USED FOR RAISING OIL PALM NURSERY

\begin{tabular}{lr}
\hline Sand $(\%)$ & 54.67 \\
Silt $(\%)$ & 8.35 \\
Clay $(\%)$ & 36.98 \\
Texture & Clayey \\
$\mathrm{pH}$ & 7.12 \\
Electrical conductivity $(\mathrm{EC})\left(\mathrm{dS} \mathrm{m}^{-1}\right)$ & 0.46 \\
Organic carbon $(\mathrm{OC})(\%)$ & 1.25 \\
Phosphorus $(\mathrm{P})(\mathrm{ppm})$ & 24.62 \\
Potassium $(\mathrm{K})(\mathrm{ppm})$ & 145.65 \\
Concentration $(\mathrm{Ca})\left(100 \mathrm{~g} \mathrm{meq}^{-1}\right)$ & 3.34 \\
Magnesium $(\mathrm{Mg})\left(100 \mathrm{~g} \mathrm{meq}^{-1}\right)$ & 2.16 \\
\hline
\end{tabular}

Oil palm seedlings were raised in polybags of $23 \mathrm{~cm} \times 15 \mathrm{~cm}$ during the primary stage and 45 $\mathrm{cm} \times 38 \mathrm{~cm}$ in secondary stage. Uniform, healthy and 65 days old oil palm seed sprouts of Tenera hybrid combination (1140 Dura x 1988 Pisifera) were used as planting material during both the years. Bioinoculants were applied thrice at four months interval whereas chemical fertilisers Di-ammonium phosphate (DAP) and complex (17:17:17) were applied manually to the nursery at monthly interval. Nursery operations like watering and weeding were carried out uniformly for all the treatments. There were no serious insect pests and diseases during the nursery period.

Lignite-based Azotobacter chroococcum $\left(1 \times 10^{8}\right.$ cfu g-1 ${ }^{-1}$, Azospirillum brasilense $\left(1 \times 10^{8} \mathrm{cfu} \mathrm{g}^{-1}\right)$, Bacillus megaterium $\left(1 \times 10^{8} \mathrm{cfu} \mathrm{g}^{-1}\right)$, Frateuria aurantia $\left(1 \times 10^{8} \mathrm{cfu}\right.$ $\mathrm{g}^{-1}$ ) and soil-based Glomus aggregatum (800 infectious propagules $\mathrm{g}^{-1}$ ) were applied to potting mixture at the time of planting of seed sprouts, shifting of primary seedlings to secondary stage bags and finally eight months after planting of sprouts and the quantity of microbial inoculants per bag used was $10 \mathrm{~g}, 25 \mathrm{~g}$ and $5 \mathrm{~g}$, respectively. In the combined treatment, Bacillus megaterium, Frateuria aurantia and Glomus aggregatum with above mentioned doses while Azotobacter chroococcum (5, 12.5 and $2.5 \mathrm{~g}$ ) and Azospirillum brasilense (5, 12.5 and $2.5 \mathrm{~g}$ ) with 50\% of the above mentioned doses per bag were mixed together and applied to the potting mixture.

\section{Physiological Observations}

Dry matter of oil palm seedlings was recorded at four stages with three months interval i.e., stage-1 after three months, stage- 2 after six months, stage- 3 after nine months and stage- 4 after 12 months at the nursery. Seedlings were separated into root, stem and leaf and recorded as fresh weight of roots $(\mathrm{g})$, stem (g) and leaf $(\mathrm{g})$ portions at four stages. Then samples were kept in hot air oven at $60^{\circ} \mathrm{C}$ and dry weight of plant parts and total dry matter was estimated by using top pan electronic balance. Gasexchange measurements like net photosynthetic rate $(\mathrm{Pn})$, transpiration $(\mathrm{E})$, stomatal conductance (Gs) and inter cellular $\mathrm{CO}_{2}$ concentration (Ci) were recorded at stage- 2 and stage- 4 by using a Portable Photosynthesis System (LI-COR Biosciences, Lincoln, USA) connected to a PLC-4 $\left(6.25 \mathrm{~cm}^{2}\right)$ leaf chamber. During measurements, incident photon flux density was $800 \mu \mathrm{mol}$ (photon) $\mathrm{m}^{-2} \mathrm{~s}^{-1}$, leaf temperature $25^{\circ} \mathrm{C}$ and ambient $\mathrm{CO}_{2}$ concentration (Ca) $360 \mu \mathrm{mol} \mathrm{mol}^{-1}$. Measurements were made on fully opened, matured and healthy leaf (third leaf from top of the canopy) under bright sunlight between 9.00-11.00 am.

\section{Biochemical Analysis}

Biochemical compounds like chlorophyll (chlorophyll $a, b$ and total chlorophyll), reducing 
sugars and total phenols in leaves were quantified at stage-2 (six months) and stage-4 (12 months) of oil palm nursery by using methods of Hiscox and Israelstam (1979), Somogyi (1952) and Malik and Singh (1980), respectively.

\section{Statistical Analysis}

Treatment effects were assessed for individual years using one way analysis of variance (ANOVA) and pooled effects were assessed using repeated measures ANOVA. Significance levels were tested at $\mathrm{p} \leq 0.5$. Post-hoc analysis was done using Least Significant Difference (LSD) test. All the statistical analysis was carried out using generalised linear model (GLM) procedure statistical software SAS version 9.3.

\section{RESULTS AND DISCUSSION}

\section{Gas Exchange Parameters}

There were significant differences among the treatments and all the treatments were found significantly superior to the control for Pn, E, Gs and $\mathrm{Ci}$ in leaves of oil palm seedlings (Table 2). Of all the treatments, $\mathrm{T}_{7}$-Consortium of bioinoculants $+25 \%$ RDF recorded the highest Pn $\left(13.85 \mu \mathrm{mol} \mathrm{m}^{-2} \mathrm{~s}^{-1}\right)$ which was highly significant to other treatments except T8 $\left(13.24 \mu \mathrm{mol} \mathrm{m}{ }^{-2} \mathrm{~s}^{-1}\right)$, T5 $\left(12.51 \mu \mathrm{mol} \mathrm{m}{ }^{-2}\right.$ $\left.\mathrm{s}^{-1}\right)$ and T6 $\left(12.49 \mu \mathrm{mol} \mathrm{m}^{-2} \mathrm{~s}^{-1}\right)$. Similar results were noticed in egg plant (Han and Lee, 2005) and banana plantlets grown under hydroponic condition (Baset Mia et al., 2009). The higher Pn at light saturation was related to the higher efficiency of ribulose biphosphate (RuBp) regeneration capacity of the host plant. This phenomenon is linked to higher Gs, higher inter cellular $\mathrm{CO}_{2}$ concentration and maximal interception of light through increased leaf surface and minimal carbon loss in the dark respiration process (Henson, 1991). Bondada and Oosterius (1998) have pointed out that Pn of the host plant is related to $\mathrm{N}$ content of leaf. The higher $\mathrm{N}$ in inoculated seedlings also might have contributed to the formation of chlorophyll which consequently might have increased the photosynthetic activity. Increased Pn (Mathur and Vyas, 1995) can be attributed to enhanced leaf area and chlorophyll content and vigorous growth of ber seedlings.

Among individual microbial fertilisers, maximum $P n$ was achieved in $\mathrm{T}_{5}$-Glomus aggregatum $\left(12.51 \mu \mathrm{mol} \mathrm{m}^{-2} \mathrm{~s}^{-1}\right)$ which was relatively better than $\mathrm{T}_{6}$-Consortium of bioinoculants $\left(12.49 \mu \mathrm{mol} \mathrm{m} \mathrm{m}^{-2}\right.$ $\mathrm{s}^{-1}$ ) and other individual bioinoculants. Enhanced photosynthetic rate in $\mathrm{T}_{5}$-Glomus aggregatum may be due to higher chlorophyll and carotenoid content in leaves (Mathur and Vyas, 1999; Krishna

TABLE 2. EFFICACY OF BIOINOCULANTS AND CHEMICAL FERTILISERS ON GAS EXCHANGE PARAMETERS OF OIL PALM SEEDLINGS GROWN IN NURSERY

\begin{tabular}{|c|c|c|c|c|c|c|c|c|c|c|c|c|}
\hline \multirow{2}{*}{ Treatment } & \multicolumn{3}{|c|}{ 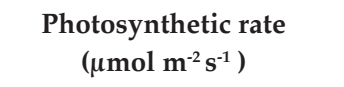 } & \multicolumn{3}{|c|}{ 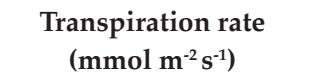 } & \multicolumn{3}{|c|}{$\begin{array}{l}\text { Stomatal conductance } \\
\left(\left(\mathrm{mmol} \mathrm{m}^{-2} \mathrm{~s}^{-1}\right)\right.\end{array}$} & \multicolumn{3}{|c|}{$\begin{array}{c}\text { Inter cellular } \mathrm{CO}_{2} \\
\text { concentration (ppm) }\end{array}$} \\
\hline & $1 \mathrm{yr}$ & $2 \mathrm{yr}$ & $\begin{array}{c}\text { Pooled } \\
\text { mean }\end{array}$ & $1 \mathrm{yr}$ & $2 \mathrm{yr}$ & $\begin{array}{c}\text { Pooled } \\
\text { mean }\end{array}$ & $1 \mathrm{yr}$ & $2 \mathrm{yr}$ & $\begin{array}{c}\text { Pooled } \\
\text { mean }\end{array}$ & $1 \mathrm{yr}$ & $2 \mathrm{yr}$ & $\begin{array}{c}\text { Pooled } \\
\text { mean }\end{array}$ \\
\hline $\mathrm{T}_{1}$ & 11.62 & 12.84 & 12.23 & 6.09 & 6.09 & 6.09 & 0.20 & 0.17 & 0.18 & 250.79 & 218.75 & 234.77 \\
\hline $\mathrm{T}_{2}$ & 11.77 & 12.18 & 11.97 & 6.50 & 5.89 & 6.20 & 0.22 & 0.17 & 0.19 & 250.43 & 208.97 & 229.70 \\
\hline $\mathrm{T}_{3}$ & 11.18 & 11.67 & 11.42 & 6.58 & 6.30 & 6.44 & 0.23 & 0.18 & 0.20 & 247.66 & 244.25 & 245.95 \\
\hline $\mathrm{T}_{4}$ & 11.45 & 11.17 & 11.31 & 6.56 & 6.34 & 6.45 & 0.20 & 0.19 & 0.19 & 248.88 & 201.77 & 225.32 \\
\hline $\mathrm{T}_{5}$ & 12.24 & 12.78 & 12.51 & 6.95 & 7.56 & 7.26 & 0.22 & 0.23 & 0.22 & 257.62 & 247.88 & 252.75 \\
\hline $\mathrm{T}_{6}$ & 12.01 & 12.97 & 12.49 & 8.34 & 7.05 & 7.69 & 0.26 & 0.20 & 0.23 & 271.26 & 233.88 & 252.57 \\
\hline $\mathrm{T}_{7}$ & 13.37 & 14.35 & 13.85 & 8.55 & 8.00 & 8.27 & 0.27 & 0.21 & 0.24 & 264.83 & 260.32 & 262.57 \\
\hline $\mathrm{T}_{8}$ & 12.96 & 13.53 & 13.24 & 8.29 & 7.72 & 8.00 & 0.24 & 0.22 & 0.22 & 261.12 & 249.84 & 255.48 \\
\hline $\mathrm{T}_{9}$ & 12.34 & 11.42 & 11.88 & 7.57 & 7.04 & 7.30 & 0.20 & 0.14 & 0.17 & 255.02 & 229.68 & 242.35 \\
\hline $\mathrm{T}_{10}$ & 11.72 & 11.99 & 11.85 & 6.54 & 6.75 & 6.64 & 0.18 & 0.13 & 0.15 & 237.76 & 227.21 & 232.48 \\
\hline $\mathrm{T}_{11}$ & 10.24 & 9.09 & 09.66 & 5.65 & 5.92 & 5.78 & 0.18 & 0.14 & 0.15 & 221.42 & 207.94 & 214.68 \\
\hline LSD-5\% & 1.07 & 1.65 & 1.38 & 0.77 & 0.58 & 0.92 & 0.03 & 0.02 & 0.03 & 15.02 & 26.92 & 17.90 \\
\hline SEM & 0.92 & 1.42 & 1.70 & 0.66 & 0.49 & 1.14 & 0.02 & 0.02 & 0.04 & 12.89 & 23.10 & 22.13 \\
\hline
\end{tabular}

Note: $\mathrm{T}_{1}$-Azotobacter chroococcum, $\mathrm{T}_{2}$-Azospirillum brasilense, $\mathrm{T}_{3}$-Bacillus megaterium, $\mathrm{T}_{4}$-Frateuria aurantia, $\mathrm{T}_{5}$-Glomus aggregatum, $\mathrm{T}_{6}-$ Consortium of bioinoculants, $\mathrm{T}_{7}$-Consortium of bioinoculants $+25 \%$ RDF, $\mathrm{T}_{8}$-Consortium of bioinoculants $+50 \%$ RDF, $\mathrm{T}_{9}$-Consortium of bioinoculants $+75 \%$ RDF, $\mathrm{T}_{10}-100 \% \mathrm{RDF}$ and $\mathrm{T}_{11}$-Control.

RDF - recommended dose of chemical fertilisers, LSD - Least Significant Difference, SEM - scanning electronic microscopy. 
et al., 2006). In addition, arbuscular mycorrhizal fungi (AMF) may function as a metabolic sink causing basipetal mobilisation of photosynthates to roots thus providing a stimulus for greater photosynthetic activity (Bevege et al., 1975). Nowak (2004) and Wu and Xia (2006) reported increased rate of photosynthesis with mycorrhiza association in geranium and citrus seedlings, respectively as compared with the control.

Treatment $\mathrm{T}_{7}$-Consortium of bioinoculants $+25 \%$ RDF $\left(8.27 \mathrm{mmol} \mathrm{m}^{-2} \mathrm{~s}^{-1}\right)$ had shown the highest E which was significantly superior to other treatments except $\mathrm{T}_{8}$-Consortium of bioinoculants+50\% RDF $\left(8.00 \mathrm{mmol} \mathrm{m} \mathrm{m}^{-2} \mathrm{~s}^{-1}\right)$ and $\mathrm{T}_{6}$-Consortium of bioinoculants $\left(7.69 \mathrm{mmol} \mathrm{m}^{-2}\right.$ $\mathrm{s}^{-1}$. Among individual bioinoculants, only the

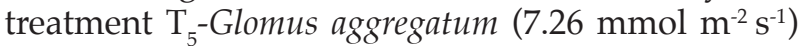
differed significantly with the control $(5.78 \mathrm{mmol}$ $\left.\mathrm{m}^{-2} \mathrm{~s}^{-1}\right)$. The present results are in agreement with the findings of Yano Melo et al. (1999) in banana plantlets. Increase in $\mathrm{E}$ might be from enhanced metabolic activity associated with AMF colonisation (Johnson and Hammel, 1985), better uptake of water as mycorrhiza in rhizosphere explores the soil better than un-inoculated roots. Further, improved water transport under well irrigated conditions may be correlated with increased $\mathrm{P}$ nutrition provided by AMF (Graham and Syversten, 1985).

Among the treatments, $\mathrm{T}_{7}$-Consortium of bioinoculants $+25 \%$ RDF $\left(0.24 \mathrm{mmol} \mathrm{m}^{-2} \mathrm{~s}^{-1}\right)$ recorded the maximum Gs and it was markedly higher than other treatments except $\mathrm{T}_{6}\left(0.23 \mathrm{mmol} \mathrm{m}^{-2} \mathrm{~s}^{-1}\right), \mathrm{T}_{8}$ $\left(0.22 \mathrm{mmol} \mathrm{m}^{-2} \mathrm{~s}^{-1}\right)$ and $\mathrm{T}_{5}\left(0.22 \mathrm{mmol} \mathrm{m}^{-2} \mathrm{~s}^{-1}\right)$. There were no significant differences among $\mathrm{T}_{5}$-Glomus aggregatum $\left(0.22 \mathrm{mmol} \mathrm{m}^{-2} \mathrm{~s}^{-1}\right), \mathrm{T}_{6}$-Consortium of bioinoculants $\left(0.23 \mathrm{mmol} \mathrm{m}^{-2} \mathrm{~s}^{-1}\right), \mathrm{T}_{7}$-Consortium of bioinoculants $+25 \%$ RDF $\left(0.24 \mathrm{mmol} \mathrm{m}^{-2} \mathrm{~s}^{-1}\right)$ and $\mathrm{T}_{8}-$ Consortium of bioinoculants $+50 \%$ RDF $(0.22 \mathrm{mmol}$ $\mathrm{m}^{-2} \mathrm{~s}^{-1}$ ) for Gs in leaves. Increased Gs in inoculated seedlings may be ascribed to higher $\mathrm{N}$ content in leaf (Bondada and Oosterius, 1998). Similarly, Nowak (2004) observed increased Gs in geranium under mycorrhisation.

Highest inter cellular $\mathrm{CO}_{2}$ concentration value in leaves was noticed in $\mathrm{T}_{7}$-Consortium of bioinoculants+25\% RDF (262.57 ppm) which was markedly superior to $\mathrm{T}_{11}$-Control (214.68 ppm) and $\mathrm{T} 10-100 \%$ RDF (232.48 ppm). Among individual bioinoculants, the best results for inter cellular $\mathrm{CO}_{2}$ concentration in leaves were noted with $\mathrm{T}_{5}$-Glomus aggregatum (252.75 ppm) followed by $\mathrm{T}_{3}$-Bacillus megaterium (245.95 ppm). The effect of $\mathrm{T}_{5}$-Glomus aggregatum (252.75 ppm) can be compared with $\mathrm{T}_{6}$-Consortium of bioinoculants (252.57 ppm) and integrated use of bioinoculants+chemical fertilisers. Further, the treatment $\mathrm{T}_{5}$-Glomus aggregatum (252.75 ppm) exhibited significant performance over $\mathrm{T}_{10}{ }^{-}$ 100\% RDF (232.48 ppm).

\section{Dry Matter Production}

The treatment $\mathrm{T}_{7}$-Consortium of bioinoculants+25\% RDF and $\mathrm{T}_{11}$-Control recorded the maximum (200.53 g) and minimum (102.91 g) dry matter among others (Table 3). Significant enhancement in seedling dry matter under $T_{7}-$ Consortium of bioinoculants $+25 \%$ RDF might be due to vigorous growth of seedlings with more number of leaves and leaflets and root density which is certainly due to greater absorption of nutrients, higher Pn, metabolic activities (Mathur and Vyas, 1999) and accumulation of nutrients in plant tissues. Findings of the present study are confirmed with reports of Aseri and Rao (2005a) in ber seedlings and Noor Aishah et al. (2009) in oil palm seedlings.

Treatment $\mathrm{T}_{10}-100 \%$ RDF had shown comparatively better results over individual bioinoculants and it was found on par with $\mathrm{T}_{6}$ Consortium of bioinoculants and $\mathrm{T}_{8}$ - Consortium of bioinoculants $+50 \% \quad \mathrm{RDF}$ and $\mathrm{T}_{9}$-Consortium of bioinoculants $+75 \%$ RDF. Similarly, Azlin et al. (2009) noticed the superiority of chemical fertilisers over individual application of bioinoculants in tissue cultured oil palm plants. Increased dry matter production can be strongly correlated with improved accumulation of $\mathrm{N}$ due to NFB, $\mathrm{P}$ due to phosphate solubilising bacteria (PSB) and AMF and $\mathrm{K}$ due to potash mobilise (Ratha Krishnan et al., 2004) in Simarouba glauca seedlings. The same trend was reported in Solanum viarum nursery (Hemashenpagam and Selvaraj, 2011) and pomegranate cuttings (Muzaffar Mir et al., 2012). Among individual treatments, $T_{5}$-Glomus aggregatum was found on par with $\mathrm{T}_{10}-100 \% \mathrm{RDF}$ and $\mathrm{T}_{6}$-Consortium of bioinoculants for dry matter production. Similarly, Nagaveni et al. (1998) in Tectona grandis reported that the growth of AMF inoculated seedlings can be compared with inorganic fertilisers.

\section{Chlorophyll}

Treatment $\mathrm{T}_{7}$-Consortium of bioinoculants $+25 \%$ RDF excelled among others by recording the maximum quantity of chlorophyll $a\left(1.13 \mathrm{mg} \mathrm{g}^{-1}\right)$, chlorophyll $b\left(0.50 \mathrm{mg} \mathrm{g}^{-1}\right)$ and total chlorophyll $\left(1.63 \mathrm{mg} \mathrm{g}^{-1}\right)$ in leaves while the minimum amount was estimated under the control (Table 3). Among individual treatments, higher values of chlorophyll $a\left(0.85 \mathrm{mg} \mathrm{g}^{-1}\right)$, chlorophyll $b\left(0.44 \mathrm{mg} \mathrm{g}^{-1}\right)$ and total chlorophyll content $\left(1.29 \mathrm{mg} \mathrm{g}^{-1}\right)$ in leaves were manifested in $\mathrm{T}_{5}$-Glomus aggregatum which was significantly superior to the control and the rest of individual treatments and it was found on par with $\mathrm{T}_{6}$-Consortium of bioinoculants and $\mathrm{T}_{10}-100 \%$ RDF. Similar results were obtained in pomegranate 
TABLE 3. EFFICACY OF BIOINOCULANTS AND CHEMICAL FERTILISERS ON DRY MATTER PRODUCTION AND CHLOROPHYLL CONTENT OF OIL PALM SEEDLINGS GROWN IN NURSERY

\begin{tabular}{|c|c|c|c|c|c|c|c|c|c|c|c|c|}
\hline \multirow{2}{*}{ Treatment } & \multicolumn{3}{|c|}{$\begin{array}{l}\text { Total dry matter } \\
\text { (g) }\end{array}$} & \multicolumn{3}{|c|}{$\begin{array}{l}\text { Chlorophyll } a \\
\quad\left(\mathrm{mg} \mathrm{g}^{-1}\right)\end{array}$} & \multicolumn{3}{|c|}{$\begin{array}{l}\text { Chlorophyll } b \\
\left(\mathrm{mg} \mathrm{g}^{-1}\right)\end{array}$} & \multicolumn{3}{|c|}{$\begin{array}{c}\text { Total chlorophyll } \\
\left.\text { (mg g } \text { g }^{-1}\right)\end{array}$} \\
\hline & $1 \mathrm{yr}$ & $2 \mathrm{yr}$ & $\begin{array}{l}\text { Pooled } \\
\text { mean }\end{array}$ & $1 \mathrm{yr}$ & $2 \mathrm{yr}$ & $\begin{array}{c}\text { Pooled } \\
\text { mean }\end{array}$ & $1 \mathrm{yr}$ & $2 \mathrm{yr}$ & $\begin{array}{c}\text { Pooled } \\
\text { mean }\end{array}$ & $1 \mathrm{yr}$ & $2 \mathrm{yr}$ & $\begin{array}{c}\text { Pooled } \\
\text { mean }\end{array}$ \\
\hline $\mathrm{T}_{1}$ & 161.54 & 118.28 & 139.91 & 0.73 & 0.73 & 0.73 & 0.31 & 0.38 & 0.34 & 1.03 & 1.10 & 1.07 \\
\hline $\mathrm{T}_{2}$ & 147.72 & 120.08 & 133.90 & 0.75 & 0.70 & 0.72 & 0.30 & 0.49 & 0.39 & 1.05 & 1.19 & 1.12 \\
\hline $\mathrm{T}_{3}$ & 156.38 & 126.04 & 141.21 & 0.79 & 0.78 & 0.78 & 0.27 & 0.43 & 0.35 & 1.05 & 1.22 & 1.13 \\
\hline $\mathrm{T}_{4}$ & 145.75 & 108.04 & 126.90 & 0.79 & 0.78 & 0.78 & 0.27 & 0.34 & 0.30 & 1.06 & 1.11 & 1.08 \\
\hline $\mathrm{T}_{5}$ & 166.88 & 140.94 & 153.91 & 0.89 & 0.81 & 0.85 & 0.38 & 0.52 & 0.44 & 1.26 & 1.32 & 1.29 \\
\hline $\mathrm{T}_{6}$ & 170.82 & 156.58 & 163.70 & 1.03 & 0.87 & 0.95 & 0.35 & 0.58 & 0.46 & 1.38 & 1.45 & 1.41 \\
\hline $\mathrm{T}_{7}$ & 232.52 & 168.54 & 200.53 & 1.17 & 1.10 & 1.13 & 0.46 & 0.54 & 0.50 & 1.63 & 1.64 & 1.63 \\
\hline $\mathrm{T}_{8}$ & 202.37 & 149.86 & 179.37 & 1.17 & 0.89 & 1.03 & 0.40 & 0.48 & 0.44 & 1.57 & 1.37 & 1.47 \\
\hline $\mathrm{T}_{9}$ & 201.07 & 143.36 & 172.21 & 1.01 & 0.82 & 0.91 & 0.36 & 0.44 & 0.40 & 1.36 & 1.25 & 1.31 \\
\hline $\mathrm{T}_{10}$ & 188.98 & 136.75 & 162.86 & 0.84 & 0.77 & 0.80 & 0.34 & 0.39 & 0.36 & 1.18 & 1.16 & 1.16 \\
\hline $\mathrm{T}_{11}$ & 137.51 & 68.31 & 102.91 & 0.69 & 0.71 & 0.70 & 0.30 & 0.29 & 0.29 & 0.99 & 1.00 & 0.99 \\
\hline LSD-5\% & 13.65 & 23.52 & 23.43 & 0.09 & 0.10 & 0.13 & 0.04 & 0.05 & 0.07 & 0.10 & 0.11 & 0.15 \\
\hline SEM & 16.82 & 28.98 & 41.21 & 0.08 & 0.09 & 0.16 & 0.03 & 0.04 & 0.09 & 0.08 & 0.09 & 0.18 \\
\hline
\end{tabular}

Note: $\mathrm{T}_{1}$-Azotobacter chroococcum, $\mathrm{T}_{2}$-Azospirillum brasilense, $\mathrm{T}_{3}$-Bacillus megaterium, $\mathrm{T}_{4}$-Frateuria aurantia, $\mathrm{T}_{5}$-Glomus aggregatum, $\mathrm{T}_{6}$-Consortium of bioinoculants, $\mathrm{T}_{7}$-Consortium of bioinoculants $+25 \%$ RDF, $\mathrm{T}_{8}$-Consortium of bioinoculants $+50 \%$ RDF, $\mathrm{T}_{9}$-Consortium of bioinoculants $+75 \%$ RDF, $\mathrm{T}_{10}-100 \%$ RDF and $\mathrm{T}_{11}$-Control.

RDF - recommended dose of chemical fertilisers, LSD - Least Significant Difference, SEM - scanning electronic microscopy.

nursery (Aseri and Rao, 2005b), guava seedlings (Panneerselvam et al., 2012) and Marsdenia volubilis seedlings (Sandhya et al., 2013). Higher stomatal conductance, photosynthesis and transpiration must be responsible for enhanced chlorophyll in AMF inoculated plants (Krishna and Bagyaraj, 1984).

Overall, chlorophyll $a$, chlorophyll $b$ and total chlorophyll contents in oil palm leaves were the maximum under integrated use of bioinoculants+chemical fertilisers. The present study confirms the reports of Aseri and Rao (2005a) in ber seedlings and Noor Aishah (2009) in oil palm seedlings. Improved chlorophyll content in inoculated seedlings is an indication of enhanced $\mathrm{Mg}, \mathrm{Fe}$ and $\mathrm{Cu}$ uptake which are essential for biosynthesis of chlorophyll in plants. Azlin et al. (2009) reported that plant-bacteria association enhances chlorophyll of tissue cultured oil palm plantlets due to indole acetic acid (IAA) production. Cytokinin produced by microbial inoculants might have become a sink to attract nutrients like $\mathrm{Mg}$, Fe and $\mathrm{K}$ which in turn might have resulted in greater synthesis of chlorophyll (Lalitha et al., 2004) in betel vine. An increase in chlorophyll content was ascribed to enhanced availability of water and minerals (Shaban and Mohsen, 2009). Significantly higher total chlorophyll content in leaves of inoculated seedlings might have resulted from enhanced stomatal conductance, carbon assimilation (Levy and Krikun, 1980) and transpiration (Hayman,
1983), plant growth and biomass production (Kolher et al., 2007; Panneerselvam et al., 2012).

\section{Reducing Sugars}

Maximum quantity of reducing sugars (Table 4) was estimated under integrated application of bioinoculants particularly with $\mathrm{T}_{7}$-Consortium of bioinoculants $+25 \%$ RDF $\left(5.08 \mathrm{mg} \mathrm{g}^{-1}\right)$ and then followed by $\mathrm{T}_{5}$-Glomus aggregatum $\left(4.65 \mathrm{mg} \mathrm{g}^{-1}\right)$, $\mathrm{T}_{6}$-Consortium of bioinoculants (3.52 $\left.\mathrm{mg} \mathrm{g}^{-1}\right)$ and $\mathrm{T}_{10}-100 \%$ RDF (3.30 $\left.\mathrm{mg} \mathrm{g}^{-1}\right)$ when compared with the control $\left(2.45 \mathrm{mg} \mathrm{g}^{-1}\right)$. Among individual bioinoculants, $\mathrm{T}_{5}$-Glomus aggregatum (4.65 mg $\mathrm{g}^{-1}$ ) recorded the highest quantity of reducing sugars in leaves and it was also significantly superior to other treatments except $\mathrm{T}_{7}$-Consortium of bioinoculants+25\% RDF (5.08 $\left.\mathrm{mg} \mathrm{g}^{-1}\right)$. This observation is corroborated with Aseri et al. (2008) who reported higher level of reducing sugars in leaves of pomegranate seedlings. Increased plant growth and biomass production and higher Pn might have boosted the production of reducing sugars in leaves of inoculated Lactuca sativa seedlings (Kolher et al., 2007).

\section{Total Phenols}

Of all the treatments, maximum and minimum quantity of total phenols (Table 4) in leaves was 
TABLE 4. EFFICACY OF BIOINOCULANTS AND CHEMICAL FERTILISERS ON REDUCING SUGARS AND TOTAL PHENOLS CONTENT IN LEAVES OF OIL PALM SEEDLINGS GROWN IN NURSERY

\begin{tabular}{|c|c|c|c|c|c|c|}
\hline \multirow[t]{2}{*}{ Treatment } & \multicolumn{3}{|c|}{$\begin{array}{l}\text { Reducing sugars } \\
\qquad\left(\mathrm{mg} \mathrm{g}^{-1}\right)\end{array}$} & \multicolumn{3}{|c|}{$\begin{array}{l}\text { Total phenols } \\
\qquad\left(\mu \mathrm{g} \mathrm{g}^{-1}\right)\end{array}$} \\
\hline & $1 \mathrm{yr}$ & $2 \mathrm{yr}$ & Pooled mean & $1 \mathrm{yr}$ & $2 \mathrm{yr}$ & Pooled mean \\
\hline $\mathrm{T}_{1}$ & 3.28 & 3.10 & 3.19 & 3.80 & 1.32 & 2.56 \\
\hline $\mathrm{T}_{2}$ & 3.87 & 3.07 & 3.47 & 3.30 & 1.29 & 2.29 \\
\hline $\mathrm{T}_{3}$ & 3.39 & 3.05 & 3.22 & 2.93 & 1.56 & 2.24 \\
\hline $\mathrm{T}_{4}$ & 2.81 & 2.64 & 2.72 & 3.08 & 1.30 & 2.19 \\
\hline $\mathrm{T}_{5}$ & 5.27 & 4.03 & 4.65 & 3.15 & 2.06 & 2.60 \\
\hline $\mathrm{T}_{6}$ & 3.70 & 3.34 & 3.52 & 3.43 & 2.18 & 2.81 \\
\hline $\mathrm{T}_{7}$ & 5.58 & 4.58 & 5.08 & 4.37 & 2.77 & 3.57 \\
\hline $\mathrm{T}_{8}$ & 3.58 & 3.79 & 3.68 & 4.05 & 2.45 & 3.25 \\
\hline $\mathrm{T}_{9}$ & 3.50 & 3.41 & 3.45 & 3.45 & 2.13 & 2.79 \\
\hline $\mathrm{T}_{10}$ & 3.51 & 3.10 & 3.30 & 3.96 & 1.86 & 2.91 \\
\hline $\mathrm{T}_{11}$ & 2.68 & 2.21 & 2.45 & 3.47 & 1.33 & 2.40 \\
\hline LSD-5\% & 0.25 & 0.26 & 0.31 & 0.21 & 0.14 & 0.22 \\
\hline SEM & 0.21 & 0.22 & 0.37 & 0.18 & 0.12 & 0.26 \\
\hline
\end{tabular}

Note: $\mathrm{T}_{1}$-Azotobacter chroococcum, $\mathrm{T}_{2}$-Azospirillum brasilense, $\mathrm{T}_{3}$-Bacillus megaterium, $\mathrm{T}_{4}$-Frateuria aurantia, $\mathrm{T}_{5}$-Glomus aggregatum, $\mathrm{T}_{6}$-Consortium of bioinoculants, $\mathrm{T}_{7}$-Consortium of bioinoculants $+25 \%$ RDF, $\mathrm{T}_{8}$-Consortium of bioinoculants $+50 \%$ RDF, $\mathrm{T}_{9}$-Consortium of bioinoculants $+75 \%$ RDF, $\mathrm{T}_{10}-100 \% \mathrm{RDF}$ and $\mathrm{T}_{11}$-Control.

RDF - recommended dose of chemical fertilisers, LSD - Least Significant Difference, SEM - scanning electronic microscopy.

recorded with $\mathrm{T}_{7}$-Consortium of bioinoculants $+25 \%$ $\operatorname{RDF}\left(3.57 \mu \mathrm{g} \mathrm{g}^{-1}\right)$ and $\mathrm{T}_{4}$-Frateuria aurantia $\left(2.19 \mu \mathrm{g} \mathrm{g}^{-1}\right)$, respectively. Higher phenol content was quantified in integrated application of bioinoculants+chemical fertilisers which were distinctly superior to the control. Similarly, results under $\mathrm{T}_{6}$-Consortium of bioinoculants $\left(2.81 \mu \mathrm{g} \mathrm{g}^{-1}\right)$ and $\mathrm{T}_{10}-100 \%$ RDF (2.91 $\mu \mathrm{g}^{-1}$ ) were significantly better than the control $\left(2.40 \mu \mathrm{g} \mathrm{g}^{-1}\right)$. The present results find support from the reports of Panneerselvam et al. (2012), Ramakrishnaiah and Vijaya (2013) and El-Quesni et al. (2013) who noticed significant improvement in phenols production in leaves/shoots of guava, pomegranate and jatropha nursery, respectively under combined use of bioinoculants in comparison with the control. Enhanced phenolic content in plant tissue can be ascribed to increased polyphenol oxidase activity (Krishna et al., 2006) and the use of accumulated nitrate in plant thus enabling it to use more carbohydrates for structural growth under the influence of biofertilisers (Hanafy Ahmed et al., 2000). Further, higher phenol content in inoculated seedlings might have resulted from enhanced plant growth and biomass production (Kolher et al., 2007). There were no significant differences for phenol content in leaves between individual bioinoculants and the control and this indicated non-effectiveness of individual microbial fertilisers.

Further, gradual decline in gas exchange parameters, chlorophyll content and dry matter production was observed when the RDF was increased from $25 \%$ to $75 \%$ under integration.

\section{CONCLUSION}

The results of the study demonstrated that inoculation of oil palm nursery seedlings with microbes vis-à-vis 100\% RDF and the control induced positive changes in gas exchange parameters, chlorophyll pigment, reducing sugars and total phenols which in turn influenced significantly the dry matter of seedlings. The treatment $T_{5}-$ Glomus aggregatum had shown significantly better performance for all the characters studied and it was equally effective when compared with consortium of bioinoculants and 100\% RDF. Overall, results clearly illustrated that integrated application of consortium of bioinoculants in combination with 25\% RDF can be a recommendation for better growth and performance of oil palm seedlings. Further, this paves a way for reduction of $75 \%$ of RDF and make oil palm nursery self-sustainable.

\section{REFERENCES}

Amir, H G; Shamsuddin, Z H and Halmi, M S (2001). Effects of Azospirillum inoculation on $\mathrm{N}_{2}$ fixation and growth of oil palm plantlets at nursery stage. J. Oil Palm Res. Vol. 13: 42-49.

Amir, H G; Shamsuddin, Z H; Halimi, M S; Ramlan, M F and Marziah, M (2005). Enhancement in nutrient accumulation and growth of oil palm seedlings caused by PGPR under field nursery conditions. 
Communications in Soil Science and Plant Analysis, 36: 2059-2066.

Aseri, G K; Neelam Jain; Jitendra Panwar; Rao, A V and Meghwal, P R (2008). Biofertilisers improve plant growth, fruit yield, nutrition, metabolism and rhizosphere enzyme activities of pomegranate in Thar Desert. Scientia Horticulture, 117: 130-135.

Aseri, G K and Rao, A V (2005a). Interaction of bio-inoculants and chemical fertilisers on biomass production, rhizosphere activity and nutrient uptake of ber. Indian J. Forestry, 28: 58-64.

Aseri, G K and Rao, A V (2005b). Significance of biofertilisers on growth and production of pomegranate in Indian arid zone. Indian J. Horticulture, 62: 398-401.

Azlin, C O; Amir, H G; Chan, L K and Zamzuri, I (2009). Root induction of tissue cultured oil palm (Elaeis guineensis Jacq.) shoot using beneficial plant growth-promoting rhizobacteria (PGPR). Biotechnology, 6: 549-554.

Baset Mia, M A; Shamsuddin, Z H; Wahab, Z and Marziah, M (2009). The effect of rhizobacterial inoculation on growth and nutrient accumulation of tissue cultured banana plantlets under low N-fertiliser regime. African J. Biotechnology, 8: 58555866.

Bevege, D I; Bowen, G D and Skinner, M F (1975). Comparative carbohydrate physiology of ecto and endomycorrhizas. Endomycorrhizas (Sanders, F E; Mosse, B and Tinker, P B eds.). Academic Press, New York. p. 149-175.

Bondada, B R and Oosterhuis, D M (1998). Relationships between nitrogen content and net gas exchange components of cotton leaf during ontogeny. Photosythetica, 35: 631-635.

El-Quesni, F E M; Hashish, K H I; Magda, M K and Azza Mazher, A M (2013). Impact of some biofertilisers and compost on growth and chemical composition of Jatropha curcas L. World Applied Science J., 21: 927-932.

Graham, J H and Syversten, J P (1985). Hostdeterminants of mycorrhizal dependency of citrus rootstock seedlings. New Phytology, 101: 667676.

Han, H and Lee, KD (2005). Phosphate and potassium solubilising bacteria effect on mineral uptake, soil availability and growth of egg plant. Research J. Agriculture and Biological Science, 1: 176-180.
Hanafy Ahmed, A H; Mishriky, J F and Khalil, M K (2000). Reducing nitrate accumulation in lettuce plants by using different biofertilisers. ICEHM2000. Cairo University, Egypt. p. 509-517.

Hayman, D S (1983). The physiology of vesicular arbuscular endomycorrhizal symbiosis. Canadian J. Botany, 61: 944-963.

Hemashenpagam, H and Selvaraj, T (2011). Effect of arbuscular mycorrizal fungus and plant growth promoting rhizomicroorganisms on medicinal plant Sonum viarum seedlings. J. Environmental Biology, 32: 579-583.

Henson, I E (1991). Adaptation to light environment by leaves of oil palm. PORIM Bulletin No. 22: 1-8.

Hiscox, J D and Israelstam, G F (1979). A method for the extraction of chlorophyll from leaf tissues without maceration. Canadian J. Botany, 57: 1332-1334.

Johnson, C R and Hammel, L (1985). Influence of mycorhizae and drought stress on growth of poncirus x citrus seedlings. Hort. Science, 20: 754-755.

Kohler, J; Caravaca, F; Carraco, L and Rolden, A (2007). Interactions between a plant growth promoting rhizobacterium, an AM fungus and phosphate solubilising fungus in the rhizosphere of Lactuca sativa. Applied Soil Ecology, 35: 480-487.

Krishna, K R and Bagyaraj, D J (1984). Growth and nutrient uptake of peanut inoculated with mycorrhizal fungus Glomus fasciculatum compared with uninoculated ones. Plant Soil, 77: 405-408.

Krishna, H; Singh, S K; Patel, U B; Khawale, R N; Deshmukh, P S and Jindal, P C (2006). Alleviation of transplanting shock by arbuscular mycorrhizal fungi in micropropagated grapevine (Vitis vinifera L.). J. Horticultural Science and Biotechology, 81: 259-263.

Lalitha, M; Karunakar Babu, M; Ravisankar, C and Ashoka Rani, Y (2004). Effect of bioregulators on chlorophyll content and keeping quality of betelvine (Piper betel L.). J. South Indian Horticulture, 52: 270-276.

Levy, J and Krikun, J (1980). Effects of vesicular arbuscular mycorrhiza on Citrus jambhiri water relations. New Phytology, 85: 25-31.

Malik, C P and Singh, M B (1980). Plants Enzymology and Histo-Enzymology. Kalyani Publishers, New Delhi. 286 pp.

Mathur, N and Vyas, V (1995). Influence of vesicular arbuscular mycorrhiza on net photosynthesis 
and transpiration of Zizyphus mauritiana. J. Plant Physiology, 147: 328-330.

Mathur, N and Vyas, V (1999). Improved biomass production, nutrient uptake and establishment of in vitro risen Ziziphus mauritiana by VA mycorrhiza. J. Plant Physiology, 155: 129-132.

Muzaffar Mir; Hassan, G I; Sheikh, K and Sanjeev Kumar Sharma (2012). Impact of biofertilisers on growth, nutrient uptake, yield, metabolism and rhizosphere enzyme activities of pomegranate (Punica granatum L.) 'Kandhari Kabuli'. Applied Biological Research, 14: 168-175.

Nagaveni, H C; Ananthapadmanabha, H S; Vijayalakshmi, G and Somasekhar, P V (1998). Comparative effect of inorganic fertilisers and VAM fungi on growth of teak plants. My Forest, 34: 697-700.

Noor Ai'shah, O; Amir, H G; Chan Lai Keng and Othman, A R (2009). Influence of various combinations of diazotrophs and chemical $\mathrm{N}$ fertiliser on plant growth and $\mathrm{N}_{2}$ fixation capacity of oil palm seedlings (Elaeis guineensis Jacq.). Thai J. Agricultural Science, 42: 139-149.

Nowak, J (2004). Effect of AMF and organic fertilisation on growth, flowering, nutrient uptake, photosynthesis and transpiration of geranium (Pelargonium hortorum Tango Orange). SymbiosisRehovot, 37: 259-266.

Panneerselvam, P; Sukhada, M; Saritha, B; Upreti, K K; Poovarasan; Mohanappa, A and Sulladmath, V V (2012). Glomus mossae associated bacteria and their influence on stimulation of mycorrhizal colonization, sporulation and growth promotion in guava seedlings. Biological Agriculture and Horticulture, 28: 267-279.

Ramakrishnaiah, G and Vijaya, T (2013). Influence of VAM fungi, Azotobacter sp. and PSB on soil phosphatase activity and nutrients status in the rhizosphere of Stevia rebaudiana (Bert.) plants. American J. Plant Science, 4: 1443-1447.

Ratha Krishnan, P; Rajapandian, J S and Kalaiselvi, $\mathrm{T}$ (2004). Influence of inoculation of biofertilisers on growth and biomass productivity of Simarouba glauca seedlings. My Forest, 40: 197-202.

Sandhya, A; Vijaya, T; Sridevi, A and Narasimha, G (2013). Influence of vesicular arbuscular mycorrhiza (VAM) and phosphate solubilising bacteria (PSB) on growth and biochemical constituents of Marsdenia volubilis. African J. Biotechnology, 12: 5648-5654.

Shaban, A E A and Mohsen, A T (2009). Response of citrus rootstocks and transplants to biofertilizers. J. Horticulture Science and Ornamental Plants, 1: 39-48.

Somogyi, M (1952). Notes on sugar determination. J. Biological Chemistry, 195: 19-23.

Wu, QS and Xia, R X (2006). Arbuscular mycorrhizal fungi influence growth, osmotic adjustment and photosynthesis of citrus under well-watered and water stress conditions. J. Plant Physiol., 16: 417-425.

Yano-Melo, A M; Saggin Junior, O J; Filho, J M; Melo, N F and Maia, L C (1999). Effect of arbuscular mycorrhizal fungi on the acclimatization of micro propagated banana plantlets. Mycorrhiza, 9: 119123. 